\title{
GOVERNANCE AND RESPONSE SERVICES IN SELECTED MUNICIPALITIES
}

\author{
Maria Wendy M. Solomo \\ Partido State University, Goa, Camarines Sur
}

Article DOI: https://doi.org/10.36713/epra7766

DOI No: 10.36713/epra7766

\begin{abstract}
The income inequality of two municipalities could affect the governance of local government units (LGUs). This study compared the governance and response of two municipalities with different income classification. It also determined the citizens' perception of corruption and people's attitude toward the LGU. This study is a comparative-descriptive type of research utilizing secondary data, particularly the Citizen Satisfaction Index System (CSIS) research reports. The second class municipality provided more services to the citizens than in the 4th class municipality. However, there was no significant difference in the citizen satisfaction $(z-v a l u e=1.93$, $p$-value $=0.0536)$ on the governance and response overall services of the 2 LGUs. There were twenty-one (21) out of 150 citizen-respondents (14\%) of the 4th class LGU experienced or encountered corruption while 11 or $7.33 \%$ of the citizens in the 2nd class LGU experienced corruption. The residents of both municipalities showed positive attitude toward the municipal government and perceived that their LGUs are moving towards the direction of its vision and attainment of its mission. Improvement of the LGU governance and response services on disaster risk reduction and management focusing on emergency preparedness in case of natural calamities and disaster such as pandemic is highly recommended.
\end{abstract}

KEYWORDS: Governance \& Response, Citizen Satisfaction, Local Government Units

\section{INTRODUCTION}

There is a large difference in the levels of corruption in developing and highly industrialized societies. Inability to view and comprehend such differences could result in injurious effects on economic theory and policy making of developing/emerging lower-middle economies (Sah, 2005). There are many cases of corruption that are not properly recorded and revealed particularly in developing countries. Sah (2005) further claimed that the level of corruption is partly determined in the nature of governance structure including the formulation and implementation of policies and laws. The governance of a certain society could be measured through the lenses of their citizens based on their experiences. Poor governance could unveil the issues on corruption and the quality of governance in terms of the services they rendered to their constituents.

Moreover, Bhagat (2005) mentioned that the rural-urban classification has a high significant impact on local governance which resulted in restructuring its system. The local revenues of the municipalities dictate the amenities and services that will be rendered to the population. He suggested that the local governments should have initiatives to augment their resources and reduce their dependence on central government funding.

The Philippines is regarded as a country that is rich both in natural resources such as copper, gold, silver, and other precious metals and human resources with around 110 million population as of 2021 (International Monetary Fund (IMF), 2021). However, the country remains a developing/emerging lower-middle economy. Why? What are the prime reasons why the country remained a poor country? The country's Gross Domestic Product is 376.8 billion US dollars in 2019, currently 33rd largest economy by nominal GDP, but declined by $9.5 \%$ in 2020 due to the COVID 19 pandemic (IMF, $2020 \& 2021)$.

Aside from challenges brought by the present pandemic and other natural hazards/disasters, widespread corruption and political oppression are primary reasons why the country remains poor despite its natural and human resources. Alba (2007) suggested that the rampant corruption during Marcos' regime increased a hundredfold after the mid-1980s resulting in slow economic development of the country. Corruption and poor governance affect the 
country's economic growth and well-being of the constituents (Rose-Ackerman, 2004) hence widespread corruption in the society could possibly lead to poor governance. In fact, based on the survey conducted by the Office of Ombudsman in 2013, soliciting bribes in the public services sector is noted and more likely to observe to Philippine officials involved in processing documents in line with civil and property registration, building permits, and other social services.

Furthermore, income, an important dimension of social organizations, is the basis in the classification of local government units (LGUs). Municipalities in the Philippines are classified into six (6) main classes based on their average annual income during the previous four calendar years (Executive Order No. 249, s. 1987). The income inequality of LGUs could affect the services and governance of municipalities. This study compared the governance and response services of two municipalities with different income classification. It also determined the citizens' perception of corruption and assessed people's attitude toward the LGU. The data could provide various stakeholders, particularly the LGUs, a basis in formulating policies and ordinances to improve their governance and response services.

\section{METHODOLOGY}

This study employed the comparativedescriptive research method to compare the governance and response of a $2^{\text {nd }}$ class municipality and a $4^{\text {th }}$ class municipality. It utilized secondary data particularly the Citizen's Satisfaction Index System (CSIS) Research Reports. The two CSIS research projects were conducted in two municipalities in 2019. Both quantitative and qualitative data were used in comparing the governance and response services of the two municipalities. Permission to use the reports was sought by the researcher from the project leaders.

The gathered data were subjected to statistical treatments. Results of the citizen satisfaction on governance and response services will be tabulated and compared. To determine the difference in the citizen satisfaction on the governance and response services of the 2 LGUs, two proportion z-test was used.

$$
\begin{aligned}
& Z=\frac{\left(\hat{p}_{1}-\hat{p}_{2}\right)-0}{\sqrt{\hat{p}(1-\hat{p})\left(\frac{1}{n_{1}}+\frac{1}{n_{2}}\right)}} \\
& \text { where: } \\
& \text { z - z-value } \\
& \mathrm{n}_{1} \text { - total number of participants in } \mathrm{LGU}_{1} \\
& \mathrm{p}_{1} \text { - proportion of participants in } \mathrm{LGU}_{1} \\
& \mathrm{n}_{2} \text { - total number of participants in } \mathrm{LGU}_{2} \\
& \mathrm{p}_{2} \text { - proportion of participants in } \mathrm{LGU}_{2} \\
& \mathrm{p} \text { - average of proportion of participants in } \mathrm{LGU}_{1} \\
& \text { and } \mathrm{LGU}_{2}
\end{aligned}
$$

\section{RESULTS AND DISCUSSION}

\begin{tabular}{|c|c|c|c|c|}
\hline \multirow[b]{2}{*}{ Service Indicator Description } & \multicolumn{2}{|c|}{$2^{\text {nd }}$ class municipality } & \multicolumn{2}{|c|}{$4^{\text {th }}$ class municipality } \\
\hline & $\begin{array}{l}\text { Satisfaction } \\
(\%)\end{array}$ & $\begin{array}{l}\text { Adjectival } \\
\text { Rating }\end{array}$ & $\begin{array}{c}\text { Satisfaction } \\
(\%)\end{array}$ & $\begin{array}{l}\text { Adjectival } \\
\text { Rating }\end{array}$ \\
\hline $\begin{array}{l}\text { Delivery of Frontline Services (Retrieval } \\
\text { of Birth and Marriage Certificates, } \\
\text { Public Records, Land Titles, Etc) }\end{array}$ & 90.83 & High & 96.63 & High \\
\hline $\begin{array}{l}\text { Local Government's Response or Action } \\
\text { on Complaints Against an Office, } \\
\text { Official or Personnel of the LGU }\end{array}$ & 97.37 & High & 97.30 & High \\
\hline $\begin{array}{l}\text { Mobile LGU Services/ Provision of } \\
\text { Municipal Services to the Barangays }\end{array}$ & 94.83 & High & - & - \\
\hline $\begin{array}{l}\text { Conflict and Dispute Resolution in The } \\
\text { Barangays }\end{array}$ & 97.62 & High & 94.44 & High \\
\hline $\begin{array}{l}\text { Timely Response on Peace and Order } \\
\text { and Public Safety-related Incidents }\end{array}$ & 97.33 & High & 94.81 & High \\
\hline Traffic Management & 96.08 & High & - & - \\
\hline $\begin{array}{l}\text { Disaster Risk Reduction and } \\
\text { Management }\end{array}$ & 94.96 & High & 95.58 & High \\
\hline
\end{tabular}

Governance and Response of the Two Municipalities The governance and response of a certain municipality could be viewed through the lenses of their citizens being the intended recipients and endusers of public services. Citizens in both municipalities were highly satisfied with all the services offered by the LGUs (Table 1).

Table 1. Comparative Results for Governance and Response of the Two (2) Municipalities 
Public Information Services

Overall Rating
96.75

89.19
High

High
78.95
High

Legend: - service not provided by the LGU

Note: The overall rating is not the average of all percentages but refers to citizens' rate of governance and response in general.

Furthermore, data revealed that there are more services provided by the 2 nd class municipality than in the 4 th class municipality. The 4 th class LGU does not provide services on traffic management, mobile LGU services, and public information services. The LGU does not experience severe traffic due to its location hence, no services offered under traffic management. In fact, many far-flung areas are unreachable by public vehicles hence some people struggle to travel. Providing mobile LGU services/provision of municipal services to barangays for efficient and faster transactions in securing documents and distribution of reliefs/financial assistance in times of pandemic and other natural disasters are a big help to those citizens that lack access to transportation. Furthermore, dissemination of information about a certain pandemic, typhoon updates, job vacancy, new ordinances, etc. could be facilitated by offering public information services, particularly to far-flung barangays.

Table 2. Z-test Results Comparing the Citizens' Satisfaction on Governance and Response Services of the 2 LGUs

\begin{tabular}{lccc}
\hline \multicolumn{1}{c}{ Service Indicator Description } & z-value & p-value & Conclusion \\
\hline $\begin{array}{l}\text { Delivery of Frontline Services (Retrieval } \\
\text { of Birth and Marriage Certificates, }\end{array}$ & 1.79 & 0.0734 & Accept Ho \\
$\begin{array}{l}\text { Public Records, Land Titles, Etc) } \\
\text { Local Government's Response or Action } \\
\text { on Complaints Against an Office, }\end{array}$ & 0.00 & 1.0000 & 0.1498 \\
$\begin{array}{l}\text { Official or Personnel of the LGU } \\
\text { Conflict and Dispute Resolution In The }\end{array}$ & 1.44 & 0.4716 \\
$\begin{array}{l}\text { Barangays } \\
\text { Timely Response on Peace and Order } \\
\text { and Public Safety-related Incidents }\end{array}$ & 0.72 & 0.7338 \\
$\begin{array}{l}\text { Disaster Risk Reduction and } \\
\text { Management } \\
\text { Overall Rating }\end{array}$ & 0.34 & 0.0536 & \\
\hline
\end{tabular}

Table 2 shows the z-test results with two proportions determining the significant differences in the level of satisfaction of the two municipalities. All governance and response services that were provided by both municipalities had no significant differences in the citizens' satisfaction. It was also noted that there was no significant difference in the citizen satisfaction $(\mathrm{z}$-value $=1.93$, $\mathrm{p}$-value $=0.0536$ ) on the governance and response overall services of the 2 LGUs.

People living in a coastal municipality with a lower average annual income are already highly satisfied with the services rendered by their LGU. Along with frontline services, faster release of documents and delivery of good service are the main reasons for satisfaction. In terms of the local government's response or action on complaints, quality and immediate response to complaints and provision for suggestion boxes are reasons for satisfaction. Residents are happy when their voices are heard by their LGU and their needs are provided immediately.

In the same way, the prime reason for satisfaction in conflict and dispute resolution, and peace and order is the immediate response of government officials. In fact, some of them claimed that their LGU is a peaceful community. Under Disaster Risk Reduction and Management, immediate response/assistance during and after calamities, and the creation of an early warning system to inform the residents of an upcoming typhoon are reasons for satisfaction. Those reasons were also noted in the $2^{\text {nd }}$ class municipality. The key to high satisfaction is a responsive, fair and transparent local government unit. It is in consonance with the principle that governance includes the capacity of governments to perform their public services effectively, efficiently and equitably (Blunt, 1995) and how conflicts are handled and resolved, and how citizens express their interests and exercise their rights (Weiss, 2000). 


\section{Citizens' Perception of Corruption in Municipalities}

Twenty-one (21) out of 150 in the $4^{\text {th }}$ class municipality as shown in Figure 1 revealed that they encountered practice of municipal or barangay officials that they considered as a form of corruption and 19 did not report the experience to a government authority considering their safety and it is regarded as a normal practice.

On the other hand, in the $2^{\text {nd }}$ class municipality, 11 out of 150 experienced incidents of corruption and only 2 or $18.18 \%$ reported the experience to a government authority because some of them claimed that it has become a normal practice and reporting will not solve the problem.

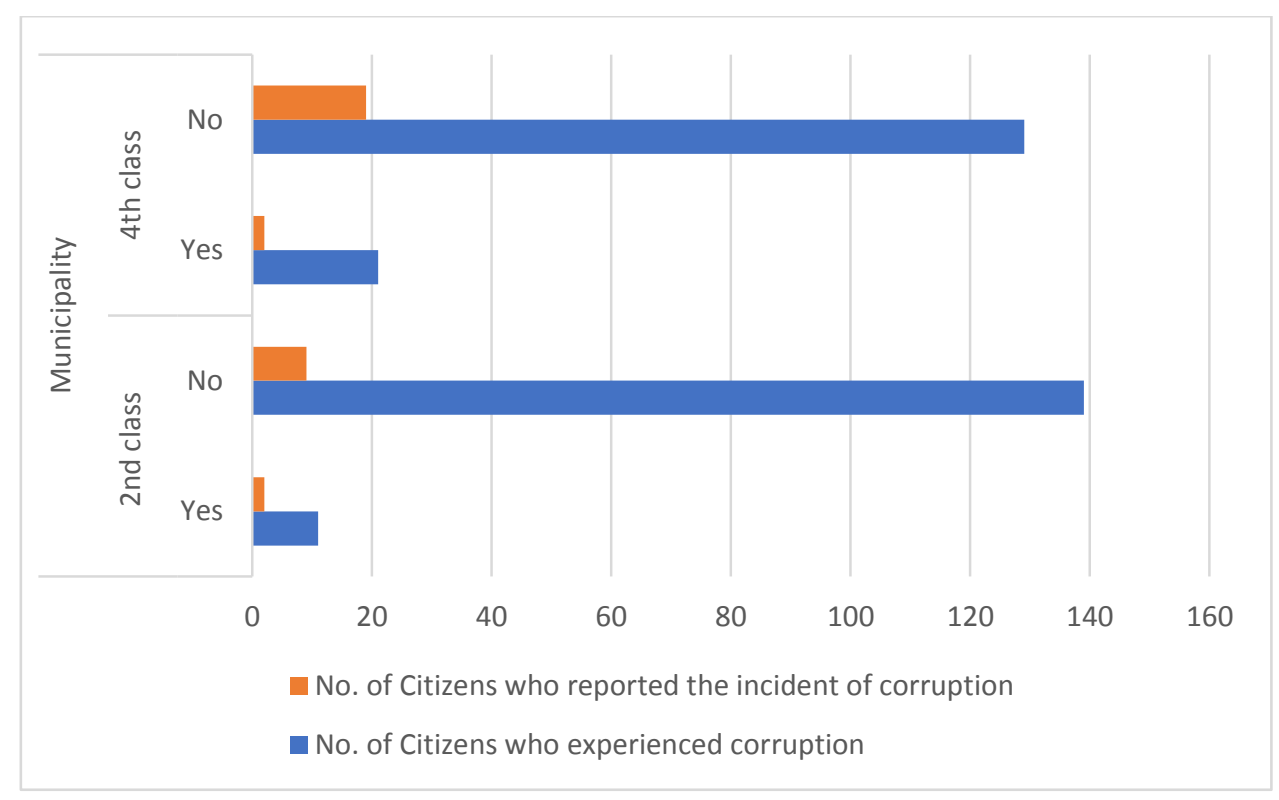

Figure 1. Comparative Results for Citizens' Perception of Corruption

Both municipalities had low ratings of incidents of corruption experienced or encountered by their constituents. However, it is worth noting that due to rampant corruption in the country since Marco's regime till the present time (Sah, 2005 \& Ong, 2003), people seemed to consider those incidents or experiences as normal practices. Furthermore, the data confirmed the results of the survey conducted by the Office of Ombudsman in 2013 that the percentage of families that reported solicitation of bribe or grease money to proper authorities for the main reason that it was not worth reporting or too small to bother. Other reasons were fear of retaliation and lack of time to report (Research and Special Studies Bureau, 2014).

\section{Citizen's General Attitude Towards Local Government Units}

The citizen-respondents of both LGUs had positive attitudes toward the municipal governments based on their responses with high adjectival ratings (Table 3). It is worth noting that majority of the residents $\left(\mathrm{M}_{1}=90 \% \& \mathrm{M}_{2}=82 \%\right)$ believed that they can declare their complaints about the local government and its officials without fear of their safety however, it contradicts the data on the number of residents who reported the incident or experience of corruption to a government authority $\left(\mathrm{M}_{1}=18 \%\right.$ $\& \mathrm{M}_{2}=11 \%$ ).

On the other hand, it is remarkable to note that many citizens $\left(\mathrm{M}_{1}=89 \%\right.$ \& $\left.\mathrm{M}_{2}=96.67 \%\right)$ considered that presenting their local problems and issues to authorities will bring something good to the community. It is consistent with the reasons of satisfaction of the residents along with the government's response or action on complaints where the provision for the suggestion box was highlighted.

On the issue of fair access to services, although rated high, got the lowest marks $\left(M_{1}=65 \%\right.$ $\& \mathrm{M}_{2}=53 \%$ ). There are people who believe that not all have equal access to services rendered by the local government, the rich and the powerful are given more priority. This perception of some citizens is confirmed in the project initiated by the Asian Development Bank that the poor and underserved communities have difficulty in accessing social services. Nevertheless, there were efforts from the local bodies to ensure equal access to services whether you are rich or poor by devising a feedback mechanism like putting a suggestion box where they 
could actually put their complaints, suggestions, and state their concerns/needs.

Table 3. Comparative Results of Citizens' General Attitude

\begin{tabular}{|c|c|c|c|c|c|c|c|c|}
\hline \multirow{4}{*}{ Parameter } & \multicolumn{8}{|c|}{ Municipality } \\
\hline & \multicolumn{4}{|c|}{$M_{1}(2 n d$ class $)$} & \multicolumn{4}{|c|}{$M_{2}$ (4th class) } \\
\hline & Yes & No & $\begin{array}{l}\% \text { of } \\
\text { those who } \\
\text { said Yes }\end{array}$ & $\begin{array}{l}\text { Adjectival } \\
\text { Rating }\end{array}$ & Yes & No & $\begin{array}{l}\% \text { of } \\
\text { those who } \\
\text { said Yes }\end{array}$ & $\begin{array}{l}\text { Adjectival } \\
\text { Rating }\end{array}$ \\
\hline & \multicolumn{3}{|c|}{$N=150$} & \multicolumn{5}{|c|}{$N=150$} \\
\hline $\begin{array}{l}\text { Can declare complaints about } \\
\text { the local government and its } \\
\text { officials without fear }\end{array}$ & 135 & 15 & $90 \%$ & High & 123 & 27 & $82 \%$ & High \\
\hline $\begin{array}{l}\text { Have have fair access to } \\
\text { services from the local } \\
\text { governments }\end{array}$ & 98 & 52 & $65 \%$ & High & 79 & 71 & $53 \%$ & High \\
\hline $\begin{array}{l}\text { Believe that presenting local } \\
\text { problems and issues to } \\
\text { authorities will result to a } \\
\text { positive outcome }\end{array}$ & 133 & 17 & $89 \%$ & High & 139 & 11 & $93 \%$ & High \\
\hline $\begin{array}{l}\text { Recommend to friends from } \\
\text { other localities to stay in the } \\
\text { municipality }\end{array}$ & 117 & 33 & $78 \%$ & High & 95 & 55 & $63 \%$ & High \\
\hline $\begin{array}{l}\text { Believe that any problem can } \\
\text { be solved by local authorities }\end{array}$ & 140 & 10 & $93 \%$ & High & 137 & 13 & $91 \%$ & High \\
\hline $\begin{array}{l}\text { View that the LGU is moving } \\
\text { towards the direction of its } \\
\text { vision }\end{array}$ & 132 & 18 & $88 \%$ & High & 145 & 5 & $96 \%$ & High \\
\hline $\begin{array}{l}\text { Perceive that the LGU is } \\
\text { doing its part in attaining its } \\
\text { mission }\end{array}$ & 134 & 16 & $89 \%$ & High & 142 & 8 & $95 \%$ & High \\
\hline $\begin{array}{l}\text { Benefit from the services } \\
\text { provided by the local } \\
\text { government }\end{array}$ & 120 & 30 & $80 \%$ & High & 112 & 38 & $75 \%$ & High \\
\hline $\begin{array}{l}\text { Perceive that taxes and fees } \\
\text { collected by the local } \\
\text { government fairly reflect the } \\
\text { quality of local programs and } \\
\text { services it provides }\end{array}$ & 112 & 38 & $75 \%$ & High & 116 & 34 & $77 \%$ & High \\
\hline
\end{tabular}

In totality, the resident-respondents in both municipalities perceived that their local governments are moving toward the direction of its vision and attainment of its mission. The citizens were happy, proud, and satisfied with the public services provided by their municipal governments.

\section{CONCLUSIONS AND}

\section{RECOMMENDATIONS}

The key to citizens' high satisfaction is a responsive, fair and efficient municipal government. There were more public services provided in a higher income municipality than in a lower income municipality. However, there was no significant difference in the citizens' satisfaction with the government and response services in the two municipalities. There are few citizens who have experienced/encountered practices of municipal or barangay officials that they perceive as a form of corruption and only two (2) in each municipality reported these incidents to government authority. In general, the citizen-respondents had a positive attitude toward their municipal governments making them proud and content with the public services provided to them.

This study recommends the following: (1) All local government units, regardless of their income classification, should offer mobile LGU services for efficient and faster transactions in securing documents, and distribution of reliefs/financial assistance in times of pandemic and other natural 
disasters.; (2) There should be a system in reporting and handling complaints and incidents of corruption to protect the identity and ensure the safety of the citizen such as creation of municipal/barangay hotline numbers or a social media page.; (3) Promote citizen participation in policy formulation and decision making through forums, referendums, and feedback mechanisms.; (4) Provide incentives/recognition to honest, hardworking and fair public servants to boost citizens' confidence in the LGU and gain public trust.

\section{REFERENCES}

1. Sah, R. (2005). Corruption across Countries and Regions: Some Consequences of Local Osmosis. 10-2005, 1-30. Research Collection School of Economics. Available at: https://ink.library.smu.edu.sg/soe_research/846

2. Bhagat, R. (2005). Rural-Urban Classification and Municipal Governance in India. Singapore Journal of Tropical Geography, 26(1), 61-73. https://doi.org/10.1111/j.0129 7619.2005.00204.x

3. Alba, M. (2007): Why has the Philippines remained a poor country? Some perspectives from growth economics, UPSE Discussion Paper, No. 2007,01, University of the Philippines, School of Economics (UPSE), Quezon City

4. Indicators of Economy in the Philippines. Retrieved from:

https://www.worlddata.info/asia/philippines/econ omy.php\#: :text $=$ Worldwide\%20gross\%20dome stic\%20product\%20in,33\%20among\%20the\%20 major\%20economies.

5. Executive Order No. 249, s. 1987. https://www.officialgazette.gov.ph/1987/07/25/ex ecutive-order-no-249-s-1987/

6. "World Economic Outlook Database. (2019). IMF.org. International Monetary Fund. Retrieved May 7, 2021

7. "World Economic Outlook Database. (2020). IMF.org. International Monetary Fund. Retrieved May 7, 2021

8. International Monetary Fund (2021). https://www.imf.org/en/Countries/PHL

9. Acemoglu, D., Naidu, S., Restrepo, P., Robinson, J. A. (2013). Democracy, redistribution and inequality. MIT Department of Economics Working Paper No. 13-24. http://ssrn.com/abstract $=2367088$ http://dx.doi.org/10.2139/ssrn.2367088

10. Rose-Ackerman, S. (2004). The Challenge of Poor Governance and Corruption. Copenhagen Consensus 2004 Project. Cambridge University Press.

11. Landes, D. (1990). "Why are we so rich and they so poor?" American Economic Review 80 (2), 113

12. Ong, J. (2003). "From term paper to putsch." Drexel Online Journal.
13. Research and Special Studies Bureau (2014). 2013 National Household Survey on Experience with Corruption in the Philippines. Office of the Ombudsman (2014).

14. Blunt, P. (1995). Cultural relativism, 'good' governance and sustainable human development. Public Administration and Development. 15 (1): 1-9. https://doi.org/10.1002/pad.4230150102

15. Weiss, T. (2000). Governance, Good Governance and Global Governance: Conceptual and Actual Challenges. Third World Quarterly, 21(5), 795814. Retrieved May 8, 2021, from http://www.jstor.org/stable/3993619 